\title{
The relationship between disease prognosis and serum calcium and corrected calcium levels in COVID-19 patients
}

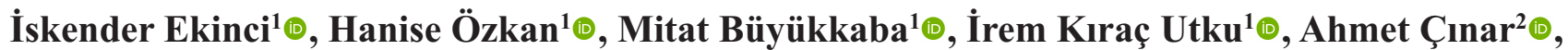 \\ Ramazan Güven $^{3 \oplus}$, Murat Akarsu' ${ }^{1}$, Abdulbaki Kumbasar ${ }^{4} \oplus$, Hafize Uzun ${ }^{5}$, Ömür Tabak ${ }^{1 \oplus}$
}

\begin{abstract}
${ }^{1}$ Department of Internal Medicine, University of Health Sciences, Kanuni Sultan Süleyman Training and Research Hospital, Istanbul, Turkey

${ }^{2}$ Department of Internal Medicine, Arnavutköy State Hospital, İstanbul, Turkey

${ }^{3}$ Department of Emergency Medicine, University of Health Sciences, Başakşehir Cam and Sakura City Hospital, İstanbul, Turkey ${ }^{4}$ Department of Internal Medicine, University of Health Sciences, Bakırköy Dr Sadi Konuk Training and Research Hospital, İstanbul, Turkey

${ }^{5}$ Department of Medical Biochemistry, Ístanbul University-Cerrahpaşa, School of Cerrahpaşa Medicine, Istanbul, Turkey
\end{abstract}

\begin{abstract}
Objectives: The present study aimed to evaluate whether low serum calcium $(\mathrm{Ca})$ and corrected calcium (cCa) levels could predict disease prognosis and mortality in patients with COVID-19.

Methods: In this study, we retrospectively enrolled 206 eligible patients with COVID-19, diagnosed at Turkey Kanuni Sultan Süleyman Training and Research Hospital between March 12, 2020 and June 15, 2020.

Results: Serum Ca level was $8.8 \pm 0.57 \mathrm{mg} / \mathrm{dL}$ and the serum cCa level was $8.99 \pm 0.53$ in all patients. The patients were divided into two groups, such as hypocalcemic and non-hypocalcemic patients. We observed that serum Ca levels of patients who died were significantly lower than that of surviving patients. A significant negative correlation was found between serum $\mathrm{cCa}$ level and albumin level. A significant positive correlation was found between serum cCa level and C-reactive protein, lactate dehydrogenase, ferritin, procalcitonin, troponin, CURB-65 score, and quick Sepsis-related Organ Failure Assessment (q-SOFA) score. Univariate logistic regression analysis revealed that age, respiratory rate, saturation, heart rate, lymphocyte, serum calcium, D-dimer, CURB-65 score, and q-SOFA score were independent predictors of high-risk group of mortality.

Conclusions: This study confirms that the severity of COVID-19 is associated with lower concentrations of serum $\mathrm{Ca}$. The cCa levels were associated with certain prognostic factors. Serum $\mathrm{Ca}$ and cCa levels could be an early and helpful marker to improve management of patients with COVID-19. We recommend evaluation of calcium in patients on initial presentation and serial monitoring during hospitalization in order to perform timely and appropriate corrective actions.
\end{abstract}

Keywords: COVID-19, mortality, calcium, corrected calcium, hypocalcemia

$\mathrm{C}$ oronavirus disease-19 (COVID-19), which was first manifested as atypical pneumonia cases in Wuhan, the capital of Hubei province of China in December 2019, was later found to be a new type of coro- navirus. The COVID-19 disease is termed SARSCoV-2 because its etiology resembles the severe acute respiratory syndrome coronavirus (SARS-CoV). COVID-19 disease continues to be a major health con- 
cern throughout the world, including Turkey $[1,2]$. Although, COVID-19 disease can usually be manifested as an asymptomatic or mild disease, its clinical course can be severe in some cases. The severe clinical course can be predicted in patients with certain clinical features; however, this cannot be done with absolute certainty. Advanced age, male gender, presence of comorbid diseases (especially hypertension, diabetes mellitus, and coronary artery disease), obesity, hypotension, tachypnea, hypoxia, lymphopenia, thrombocytopenia, hypoalbuminemia, impaired renal function, high levels of C-reactive protein (CRP), Ddimer, procalcitonin, interleukin-6 (IL-6), ferritin, alanine transaminase (ALT), aspartate transaminase (AST), lactate dehydrogenase (LDH), and the presence of ground glass opacity on tomography have been reported to be poor prognostic factors for the disease [1, 3-11].

SARS-CoV-2 binds to the angiotensin-converting enzyme (ACE)-2 receptor through the $S$ protein and enters the respiratory tract and causes cell damage through cytopathic effect and cytokine release [12]. Calcium $(\mathrm{Ca} 2+)$ is an important molecule in viral infections for the formation of the virus structure, entry of the virus into the cell, gene expression, virion maturation, and release [13]. In vitro experimental studies and studies on animal models infected with SARS$\mathrm{CoV}$ have demonstrated that the SARS-CoV E gene encodes a small transmembrane protein that is highly expressed during infection and has ion channel activity. It has been reported that these ion channels are permeable to calcium and activate inflammatory pathways through intracellular calcium homeostasis changes, disrupt the host cell system, and facilitate the replication of the virus [14-16]. The similarity between SARS-CoV-2 and SARS-CoV genomes suggests that a similar mechanism may be effective.

Serum Ca level abnormalities are common in hospitalized patients and are known to be associated with mortality [17]. While some studies reported higher mortality in hypocalcemic cases, other studies reported that hypercalcemic cases had higher mortality rates $[18,19]$. However, there are no studies that have actually studied this hypothesis in patients with COVID-19. The fact that the calcium molecule plays an active role in the host cell-virus interactions prompt us to think that the differences in calcium levels can cause differences in the effects of the virus on the host cell and can thereby affect the course of the disease. Therefore, this study aimed to investigate the factors affecting the relationship between disease prognosis and mortality with serum $\mathrm{Ca}$ and corrected calcium (cCa) levels in patients with COVID-19.

\section{METHODS}

\section{Study Design}

The protocol of the current study was approved by the ethics committee of Health Sciences University, Kanuni Sultan Süleyman Research and Training Hospital (No: KAEK/2020.06.114). This retrospective study was conducted in the Health Sciences University, Kanuni Sultan Suleyman Research and Training Hospital, Department of Internal Medicine. We enrolled 206 patients diagnosed with COVID-19 between March 12, 2020 and June 15, 2020 in this study.

\section{Patient Characteristics and Data Collection}

This retrospective cross-sectional study was carried out utilizing the medical records of patients who were hospitalized in isolated wards with the diagnosis of COVID-19 in a tertiary education and research hospital. In this study, we included patients with positive SARS-CoV-2 RNA detection in throat swab samples and who were diagnosed with COVID-19 according to the World Health Organization (WHO) guidelines. All patients were of Turkish descent.

We recorded the treatments received by the patients, duration of hospitalization, and the disease outcome (survival or nonsurvival). Demographic data of the patients (age, gender, hospital admission complaints, and comorbid diseases) and vital signs at the time of admission (presence of fever, heart rate, percentage of oxygen saturation on room air, and minuterespiration rate) were obtained from the patient's medical record. Laboratory data [complete blood count (CBC), CRP, creatinine, ALT, AST, albumin, calcium, LDH, D-dimer, fibrinogen, ferritin, procalcitonin (PCT), and troponin] and imaging analysis of the patients at the time of admission (presence of lung involvement on chest tomography; and if there is involvement, whether it is unilateral or bilateral and presence of consolidation and ground glass appearance) were obtained from the medical records.

Patients under the age of 18 , patients whose serum 
Ca level was not checked at the time of hospital admission, pregnant women, breastfeeding women, patients with comorbidities that may affect serum calcium levels (such as primary hyperparathyroidism, hypoparathyroidism, malignancy, multiple myeloma, osteoporosis, granulomatous diseases, and pancreatitis), and patients who were on medications within the last 1 month that could affect serum calcium levels (such as lithium, vitamin D, thiazide diuretics, and bisphosphonates) were not included in this study.

The cCa level (mg/dL) was calculated using the following formula: measured serum Ca level $(\mathrm{mg} / \mathrm{dL})$ $+0.8 \times[(4-$ serum albumin $(\mathrm{g} / \mathrm{dL})]$. Patients with serum Ca level or serum cCa level $<8.5 \mathrm{mg} / \mathrm{dL}$ were defined as the "hypocalcemic group," and patients with serum $\mathrm{Ca}$ level or serum cCa level $\geq 8.5 \mathrm{mg} / \mathrm{dL}$ were defined as the "non-hypocalcemic group."

The CURB-65 score was calculated by considering 1 point for each of the following conditions: confusion, respiratory rate $\geq 30 / \mathrm{min}$, systolic blood pressure $<90 \mathrm{mmHg}$ or diastolic blood pressure $<60$ $\mathrm{mmHg}, \mathrm{BUN}>19 \mathrm{mg} / \mathrm{dL}$, and age $\geq 65$.

q-SOFA score was calculated by considering 1 point for each of the following parameters: abnormal state of consciousness, respiratory rate $\geq 22 / \mathrm{min}$, and systolic blood pressure $\leq 100 \mathrm{mmHg}$.

Samples were tested using the WHO recommendations and national guidelines [20].

\section{Laboratory Procedures}

Blood samples were obtained prior to treatment and collected into standardized tubes containing EDTA for analysis of CBC parameters and standardized tubes without any anticoagulant for the biochemical analysis. Serum samples that were obtained after centrifugation at $2500 \mathrm{~g}$ for $5 \mathrm{~min}$ were used directly for the measurements of biochemical parameters.

CBC was analyzed by a Sysmex XT 1800i device (ROCHE-2011, Kobe, Japan). Ca and other biochemical parameters were analyzed by a COBAS 8000 device (ROCHE-2007, Tokyo, Japan).

CRP analysis was performed using the immunoturbidimetric method (ROCHE DIAGNOSTICS HITACHI, Tokyo, Japan).

Plasma fibrinogen was measured by using Clauss method using Fibrintimer II coagulometer and Multifibren U kit (Siemens Healthcare Diagnostics, Germany).
D-dimer analysis was carried out on plasma collected into 3.2\% buffered sodium citrate blood tubes (Becton Dickinson, Franklin Lakes, NJ, USA), using Stago coagulation analyzers STA compact Max 3 (Stago, Asnières-sur-Seine, France) and proprietary reagents by immunoturbidimetric method.

Ferritin, PCT, and troponin were measured in VIDAS (BioMerieux Inc. France)) device by electrochemiluminescence immunoassay (ECLIA) method.

Oxygen saturation was measured every 4 hours using a digital saturometer. Oxygen flow was calculated to obtain oxygen saturation between $90 \%$ and $94 \%$.

\section{Computed Tomography (CT)}

We used a multidetector CT scanner (Toshiba Aquilon; Toshiba, Inc., Tokyo, Japan) with the following parameters: tube voltage, $120 \mathrm{kV}$; tube current, 110 $\mathrm{mAs}$ (automatic adjustment); rotation time, $0.5 \mathrm{sec}$ ond; section thickness, $0.75 \mathrm{~mm}$; collimation, $0.6 \mathrm{~mm}$; pitch, 1; matrix, $512 \times 512$; and inspiration breath hold. Axial, sagittal, and coronal reformatted images were created with a slice thickness of 3-mm.

\section{Analysis of RT-PCR Test}

SARS-CoV-2 was detected by real time polymerase chain reaction method in oropharyngeal/nasopharyngeal swab samples.

\section{Statistical Analysis}

SPSS 21.0 program was used for data analysis. Nominal variables were expressed as number and percentage, whereas numeric variables were represented as mean \pm standard deviation or median. Kolmogorov-Smirnov test was performed to determine whether the continuous variables were normally or non-normally distributed. Normally distributed independent continuous variables were compared with the independent t-test, whereas non-normally distributed independent continuous variables were compared with the Mann-Whitney U test among the groups. A univariate regression analysis was performed to observe the effects of possible parameters on mortality. In order to evaluate the relationship between serum $\mathrm{Ca}$ level and mortality, we determined a cut-off value for serum $\mathrm{Ca}$ level by the receiver operating characteristic (ROC) analysis. A two-tailed $p$ value of $<0.05$ was considered to be statistically significant. In the power 
analysis made through the GPower 3.1.9.4 program, it has been determined that the achieved power value (1- $\beta$ err prob) of the study is 1 .

\section{Table 1. Demographic data of patients}

\begin{tabular}{|c|c|c|}
\hline Gender & $\mathbf{n}$ & $\%$ \\
\hline Male & 113 & 54.9 \\
\hline Female & 93 & 45.1 \\
\hline \multicolumn{3}{|l|}{$\begin{array}{l}\text { Complaint of admission } \\
\text { time }\end{array}$} \\
\hline Cough & 148 & 71.8 \\
\hline Fever & 114 & 55.3 \\
\hline Weakness & 96 & 45.1 \\
\hline Shortness of breath & 88 & 42.7 \\
\hline Myalgia & 36 & 17.5 \\
\hline Sore throat & 15 & 7.3 \\
\hline Headache & 9 & 4.4 \\
\hline Diarrhea & 5 & 2.4 \\
\hline \multicolumn{3}{|l|}{ Treatment options } \\
\hline Hydroxychloroquine & 205 & 99.5 \\
\hline Azithromycin & 195 & 94.7 \\
\hline Oseltamivir & 120 & 58.3 \\
\hline Favipiravir & 27 & 13.1 \\
\hline Additional antibiotic & 40 & 19.4 \\
\hline $\begin{array}{l}\text { Intravenous fluid } \\
\text { replacement }\end{array}$ & 34 & 16.5 \\
\hline Oxygen support & 83 & 40.3 \\
\hline Enoxaparin sodium & 126 & 61.2 \\
\hline \multicolumn{3}{|l|}{ Comorbid diseases } \\
\hline Hypertension & 73 & 35.4 \\
\hline $\begin{array}{l}\text { Type- } 2 \text { Diabetes } \\
\text { mellitus }\end{array}$ & 43 & 20.9 \\
\hline $\begin{array}{l}\text { Chronic obstructive } \\
\text { pulmonary disease }\end{array}$ & 25 & 12.1 \\
\hline $\begin{array}{l}\text { Coronary artery } \\
\text { disease }\end{array}$ & 25 & 12.1 \\
\hline $\begin{array}{l}\text { Immunological } \\
\text { disease }\end{array}$ & 5 & 2.4 \\
\hline $\begin{array}{l}\text { Cerebrovascular } \\
\text { disease }\end{array}$ & 3 & 1.5 \\
\hline \multicolumn{3}{|l|}{ Tomography findings } \\
\hline $\begin{array}{l}\text { Unilateral } \\
\text { involvement }\end{array}$ & 25 & 12.1 \\
\hline Bilateral involvement & 158 & 76.7 \\
\hline $\begin{array}{l}\text { No pulmonary } \\
\text { involvement }\end{array}$ & 23 & 11.2 \\
\hline Ground glass opacity & 175 & 85 \\
\hline $\begin{array}{l}\text { Presence of } \\
\text { consolidation }\end{array}$ & 105 & 51 \\
\hline \multicolumn{3}{|l|}{ Outcome } \\
\hline Recovered & 194 & 94.2 \\
\hline Died & 12 & 5.8 \\
\hline
\end{tabular}

\section{RESULTS}

In this study we included 206 patients (113 males, 93 females) with a mean age of $55.1 \pm 15.7$ years (range: 19-92 years). The demographic data of the patients are presented in Table 1.

The most common complaint of these patients was cough, the next common complaint being high fever. The most common comorbid diseases were determined as hypertension, type- 2 diabetes mellitus, obstructive pulmonary diseases, and coronary artery disease. The number of patients with at least 1 comorbid disease was $104(50.5 \%)$, the number of patients with at least 2 comorbid diseases was 60 (29.1\%), whereas the number of patients with 3 or more comorbid diseases was $19(9.2 \%)$. Chest tomography demonstrated bilateral lung involvement (76.7\%) and ground glass appearance $(85 \%)$ in majority of the patients, consolidation $(51 \%)$ was observed in nearly half of the cases, whereas 23 patients demonstrated no signs of pneumonia. Most of the patients received hydroxychloroquine and azithromycin therapy, and more than half of the patients also received enoxaparin sodium and oseltamivir. The mean duration of hospitalization of the patients was $7.1 \pm 3.3$ days $(2-19$ days). Twelve patients (5.8\%) succumbed to the disease.

When all patients were taken into consideration, serum Ca level was found to be $8.8 \pm 0.57 \mathrm{mg} / \mathrm{dL}$ and serum Ca level was found to be $8.99 \pm 0.53 \mathrm{mg} / \mathrm{dL}$. The results obtained when the patients were grouped and compared as hypocalcemic and nonhypocalcemic are presented in Table 2.

The serum Ca levels of patients who died were significantly lower than those of patients who survived ( $8.4 \pm 0.64$ vs. $8.83 \pm 0.56, p=0.013$ ), but there was no significant difference between serum cCa levels $(9.08 \pm 0.6$ vs. $8.98 \pm 0.53, p=0.544)$. No significant difference was found between serum $\mathrm{Ca}$ levels of patients with and without pneumonic infiltration $(8.80 \pm$ 0.55 vs. $8.83 \pm 0.71, p=0.844$ ), with at least one comorbid disease or no comorbid disease $(8.85 \pm 0.60$ vs. $8.75 \pm 0.54, p=0.188$ ), and who were using ACE inhibitors/angiotensin II receptor blockers or who did not use these drugs $(8.93 \pm 0.64$ vs. $8.77 \pm 0.55, p=$ 0.140 ).

The results obtained in the univariate regression analysis for the parameters predicted to have an effect 
Table 2. Comparison of the patients in terms of serum calcium and corrected serum calcium levels

\begin{tabular}{|c|c|c|c|c|c|c|}
\hline & \multicolumn{2}{|c|}{ Serum calcium } & \multirow[t]{2}{*}{$p$ value } & \multicolumn{2}{|c|}{ Corrected serum calcium } & \multirow[t]{2}{*}{$p$ value } \\
\hline & $\begin{array}{c}<8.5 \mathrm{mg} / \mathrm{dL} \\
\quad(\mathrm{n}=57)\end{array}$ & $\begin{array}{l}\geq 8.5 \mathrm{mg} / \mathrm{dL} \\
\quad(\mathrm{n}=149)\end{array}$ & & $\begin{array}{c}<8.5 \mathrm{mg} / \mathrm{dL} \\
(\mathrm{n}=42)\end{array}$ & $\begin{array}{l}\geq 8.5 \mathrm{mg} / \mathrm{dL} \\
\quad(\mathrm{n}=164)\end{array}$ & \\
\hline Age (year) & $55.01 \pm 15.91$ & $55.2 \pm 15.78$ & $0.94 *$ & $52.02 \pm 15.81$ & $55.95 \pm 15.72$ & $0.104 * *$ \\
\hline $\operatorname{Sex}(\mathrm{F} / \mathrm{M})$ & $22 / 35$ & $71 / 78$ & $0.275 \#$ & $17 / 25$ & $76 / 88$ & $0.603 \#$ \\
\hline $\begin{array}{l}\text { Hospitalization duration } \\
\text { (day) }\end{array}$ & $7.59 \pm 3.68$ & $7.03 \pm 3.28$ & $0.32 * *$ & $7.19 \pm 3.46$ & $7.18 \pm 3.39$ & $0.922 * *$ \\
\hline Respiratory rate (min) & $19.64 \pm 2.87$ & $19.48 \pm 2.62$ & $0.956^{* *}$ & $19.66 \pm 2.97$ & $19.49 \pm 2.61$ & $0.897 * *$ \\
\hline Heart rate $(\mathrm{min})$ & $89.43 \pm 11.87$ & $85.47 \pm 9.88$ & $0.016 * *$ & $87.69 \pm 12.06$ & $86.28 \pm 10.19$ & $0.617 * *$ \\
\hline Saturation $(\%)$ & $92.05 \pm 10.93$ & $93.81 \pm 5.65$ & $0.569 * *$ & $92.57 \pm 12.28$ & $93.51 \pm 5.72$ & $0.43 * *$ \\
\hline Calcium (mg/dL) & $8.16 \pm 0.29$ & $9.05 \pm 0.45$ & $<0.001 *$ & $8.15 \pm 0.34$ & $8.97 \pm 0.49$ & $<0.001 *$ \\
\hline $\begin{array}{l}\text { Corrected serum calcium } \\
(\mathrm{mg} / \mathrm{dL})\end{array}$ & $8.56 \pm 0.43$ & $9.15 \pm 0.47$ & $<0.001^{*}$ & $8.36 \pm 0.32$ & $9.15 \pm 0.45$ & $<0.001 *$ \\
\hline WBC $(103 \mu / L)$ & $6.31 \pm 2.66$ & $7.04 \pm 3.07$ & $0.093 * *$ & $5.65 \pm 2.32$ & $7.14 \pm 3.06$ & $0.001 * *$ \\
\hline $\mathrm{Hb}(\mathrm{g} / \mathrm{dL})$ & $13.74 \pm 7.97$ & $13.18 \pm 1.64$ & $0.297 * *$ & $12.76 \pm 2$ & $13.48 \pm 4.82$ & $0.368 * *$ \\
\hline Neutrophil $(103 \mu / \mathrm{L})$ & $4.31 \pm 2.19$ & $4.92 \pm 4.91$ & $0.529 * *$ & $3.72 \pm 1.78$ & $5.01 \pm 4.74$ & $0.017 * *$ \\
\hline Lymphocyte $(103 \mu / \mathrm{L})$ & $1.335 \pm 0.84$ & $1.77 \pm 1.39$ & $0.001 * *$ & $1,39 \pm 0,73$ & $1.72 \pm 1.37$ & $0.087 * *$ \\
\hline Platelet, $(103 \mu / \mathrm{L})$ & $213.63 \pm 80.34$ & $258.45 \pm 100.8$ & $0.001 * *$ & $199.92 \pm 54.69$ & $257.9 \pm 102.5$ & $<0.001 * *$ \\
\hline CRP (mg/L) & $65.48 \pm 54.67$ & $45.35 \pm 53.28$ & $0.001 * *$ & $51.32 \pm 42.98$ & $50.82 \pm 56.94$ & $0.251 * *$ \\
\hline Creatinine (mg/dL) & $1.33 \pm 1.34$ & $0.88 \pm 0.32$ & $0.008 * *$ & $1.36 \pm 1.52$ & $0.91 \pm 0.37$ & $0.189 * *$ \\
\hline $\operatorname{ALT}(\mathrm{U} / \mathrm{L})$ & $50.84 \pm 173.31$ & $32.21 \pm 26.64$ & $0.692 * *$ & $27.19 \pm 17.7$ & $39.97 \pm 104.6$ & $0.326^{* *}$ \\
\hline AST, (U/L) & $47.07 \pm 120$ & $30.85 \pm 21.04$ & $0.07 * *$ & $31.73 \pm 12.90$ & $36.26 \pm 73.3$ & $0.112 * *$ \\
\hline Albumin, $(\mathrm{g} / \mathrm{L})$ & $3.49 \pm 0.5$ & $3.87 \pm 0.43$ & $<0.001^{*}$ & $3.74 \pm 0.46$ & $3.73 \pm 0.49$ & $0.698^{*}$ \\
\hline LDH (U/L) & $312.8 \pm 106.17$ & $271.9 \pm 90.87$ & $0.01^{*}$ & $299.7 \pm 92.9$ & $279.8 \pm 98.17$ & $0.263^{*}$ \\
\hline D-dimer (mg/L) & $1.81 \pm 5.22$ & $1.17 \pm 2.84$ & $0.637 * *$ & $1.04 \pm 2.13$ & $1.42 \pm 3.93$ & $0.409 * *$ \\
\hline Fibrinogen (mg/dL) & $428.2 \pm 136.3$ & $420.1 \pm 150.9$ & $0.378 * *$ & $388.1 \pm 75.7$ & $431.4 \pm 158.2$ & $0.559 * *$ \\
\hline Ferritin $(\mathrm{mg} / \mathrm{mL})$ & $664.2 \pm 177.8$ & $334.1 \pm 376.9$ & $0.016^{* *}$ & $724.69 \pm 212.8$ & $356.1 \pm 390.8$ & $0.277 * *$ \\
\hline Procalcitonin $(\mathrm{mg} / \mathrm{mL})$ & $0.38 \pm 1.04$ & $0.08 \pm 0.15$ & $0.007 * *$ & $0.20 \pm 0.53$ & $0.15 \pm 0.59$ & $0.869 * *$ \\
\hline Troponin $(\mathrm{mg} / \mathrm{mL})$ & $0.024 \pm 0.042$ & $0.016 \pm 0.025$ & $0.498 * *$ & $0.020 \pm 0.035$ & $0.017 \pm 0.03$ & $0.881 * *$ \\
\hline CURB-65 score & $0.85 \pm 0.93$ & $0.51 \pm 0.82$ & $0.011 *$ & $0.64 \pm 0.9$ & $0.6 \pm 0.86$ & $0.795^{*}$ \\
\hline q-SOFA score & $0.66 \pm 0.8$ & $0.45 \pm 0.78$ & $0.089 *$ & $0.5 \pm 0.7$ & $0.51 \pm 0.81$ & $0.894 *$ \\
\hline
\end{tabular}

*: Student T test, **: Mann Whitney U test, \#: Ki kare test

$\mathrm{WBC}=$ White Blood Cell, $\mathrm{Hgb}=$ Hemoglobin, $\mathrm{CRP}=\mathrm{C}$-reactive protein, $\mathrm{ALT}=$ Alanine transferasis, $\mathrm{AST}=\mathrm{Aspartat}$ transferasis, $\mathrm{LDH}=$ Lactat dehidrogenasis, q-SOFA = Quick Sepsis-related Organ Failure Assessment

on mortality are presented in Table 3 . When incorporated into the univariate analysis, age, respiratory rate, saturation, heart rate, lymphocyte, serum $\mathrm{Ca}$, D-dimer, CURB-65 score, and q-SOFA score remained as significant predictors of mortality. CRP, ferritin, corrected calcium and PCT were not associated with mortality. In the correlation analysis, a positive correlation was observed between serum Ca level and lymphocyte ( $\mathrm{r}$ : $0.14, p=0.045)$, platelet (r: $0.262, p<0.001)$, and albumin (r: $0.436, p<0.001$ ); and a negative correlation was found between serum Ca level and CRP (r: $-0.291, p<0.001)$, LDH (r: $-0.335, p<0.001)$, crea- tinine ( $\mathrm{r}:-0.219, p=0.002)$, ferritin $(\mathrm{r}:-0.305, p<$ 0.001 ), procalcitonin ( $\mathrm{r}:-0.237, p=0.001)$, and CURB-65 score ( $\mathrm{r}:-0.148, p=0.033)$. There was a positive correlation between serum cCa level and CRP (r: 0.23, $p=0.003), \mathrm{LDH}(\mathrm{r}: 0.252, p=0.002)$, ferritin (r: 0.304, $p<0.001$ ), procalcitonin (r: 0.241, $p=$ $0.002)$, troponin ( $\mathrm{r}: 0.381, p<0.001), \mathrm{CURB}-65$ score (r: $0.205, p=0.008)$, and q-SOFA score (r: 0.176, $p=$ $0.024)$. On the contrary, there was a negative correlation between cCa level and albumin level (r: -0.303 , $p<0.001)$.

Using the ROC analysis, the cut-off value of 
Table 3. Univariate regression analysis for parameters predicted to have an effect on mortality

\begin{tabular}{lccc}
\hline & & Univariate & \\
\hline Variable & OR & $\mathbf{9 5 \%}$ Cl & $\boldsymbol{p}$ value \\
Age & 0.927 & $0.885-0.970$ & $\mathbf{0 . 0 0 1}$ \\
Respiratory rate, min & 0.672 & $0.549-0.822$ & $<\mathbf{0 . 0 0 1}$ \\
Saturation, \% & 1.049 & $1.005-1.094$ & $\mathbf{0 . 0 2 8}$ \\
Heart rate, min & 0.932 & $0.887-0.980$ & $\mathbf{0 . 0 0 6}$ \\
Lymphocyte, $103 \mu / \mathrm{L}$ & 3.064 & $1.038-9.046$ & 0.043 \\
CRP, mg/mL & 0.992 & $0.984-1.001$ & 0.07 \\
Serum calcium, $\mathrm{mg} / \mathrm{dL}$ & 3.960 & $1.328-11.806$ & $\mathbf{0 . 0 1 4}$ \\
Corrected serum calcium, $\mathrm{mg} / \mathrm{dL}$ & 0.719 & $0.250-2.068$ & 0.541 \\
D-dimer, $\mathrm{mg} / \mathrm{L}$ & 0.871 & $0.83-0.970$ & $\mathbf{0 . 0 1 2}$ \\
Ferritin, $\mathrm{mg} / \mathrm{mL}$ & 0.999 & $0.998-1.000$ & 0.251 \\
Procalcitonin, $\mathrm{mg} / \mathrm{mL}$ & 0.64 & $0.378-1.096$ & 0.105 \\
CURB-65 score & 0.222 & $0.111-0.447$ & $<\mathbf{0 . 0 0 1}$ \\
q-SOFA score & 0.094 & $0.032-0.275$ & $<\mathbf{0 . 0 0 1}$ \\
\hline
\end{tabular}

serum $\mathrm{Ca}$ level to examine the relationship between serum $\mathrm{Ca}$ level and mortality was determined as $>8.3$ $\mathrm{mg} / \mathrm{dL}$. As presented in fig.1, mortality was significantly lower if serum Ca was $>8.3 \mathrm{mg} / \mathrm{dL}(p=0.028$, AUC: 0.681 , sensitivity: $79.9 \%$, specificity: $50 \%$ ).

\section{DISCUSSION}

Since there is a high prevalence of hypocalcemia in COVID-19 patients and also due to the fact that hypocalcemia helps in predicting the need for hospi-

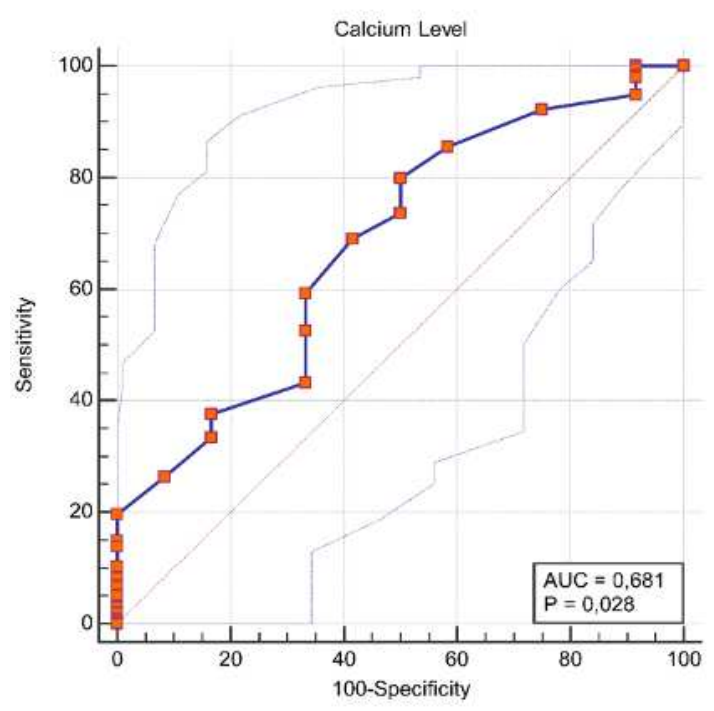

Fig. 1. ROC analysis for serum calcium. talization, it is recommended that $\mathrm{Ca}$ should always be evaluated initially during hospitalization to identify more severe patients [21-23]. We observed that serum Ca levels of the patients who died were significantly lower than that of the patients who survived. Furthermore, there was a significantly lower mortality in patients with serum $\mathrm{Ca}>8.3 \mathrm{mg} / \mathrm{dL}$ (sensitivity: $79.9 \%$, specificity: $50 \%$ ) according to the ROC analysis. This study revealed that serum Ca level is a good prognostic parameter in COVID-19 patients and is an independent determinant for mortality. Patients with hypocalcemia have worse prognostic parameters. Moreover, cCa levels were associated with certain prognostic factors.

Sun et al. [21] reported that the prognostic parameters of patients with COVID-19 with hypocalcemia are worse and the rates of organ failure, septic shock, and mortality are higher. In addition, they stated that the serum Ca level was associated with the severity and prognosis of the disease. In the same study, it was reported that there was a positive correlation between serum $\mathrm{Ca}$ and lymphocyte, albumin and $\mathrm{SpO} 2$; and a negative correlation between serum $\mathrm{Ca}, \mathrm{CRP}$, and $\mathrm{D}-$ dimer and that serum $\mathrm{Ca}$ levels of patients who died were lower [21]. In another study which included 585 patients who visited the emergency department with suspicion of COVID-19, patients who were diagnosed with COVID-19 and who were not diagnosed with 
COVID-19 were evaluated for serum total and ionized $\mathrm{Ca}$, and it was reported that serum total $\mathrm{Ca}$ and ionized $\mathrm{Ca}$ levels were lower in COVID-19 patients. It has been stated that the total $\mathrm{Ca}$ and ionized $\mathrm{Ca}$ levels decrease in COVID-19 patients as the age increases, and these values are lower in the male gender [22]. In a retrospective cohort study, it was reported that a high rate of hypocalcemia was detected in patients with COVID-19 at the time of presentation, and this was more common in male and patients with advanced age [23]. In the same study, it was stated that serum $\mathrm{Ca}$ levels of patients requiring hospitalization were lower than those not requiring hospitalization, and that serum $\mathrm{Ca}$ levels after hospitalization were closely associated with both, death and transfer to the intensive care. Bossoni et al. [24] reported severe hypocalcemia in a woman with COVID-19 disease who had underwent thyroidectomy and suggested $\mathrm{Ca}$ evaluation and monitoring in all hospitalized patients with COVID19 infection. Another study reported that calcium, sodium, and potassium concentrations were significantly lower in patients with severe COVID-19 [25]. Cao et al. [26] observed that $65.4 \%$ of patients with COVID-19 had decreased serum Ca levels. Compared with the non-intensive care unit (ICU) patients, the patients admitted to the ICU were more likely to have low serum calcium (100\% vs $61.4 \%)$. According to their results, as the $\mathrm{Ca}$ levels decreased, the severity of the disease increased. Ca2+ levels and/or $\mathrm{Ca} 2+$ channels may play a role in endocytosis and infection of SARS-Cov-2. Further studies are warranted to characterize the functional importance of this potential pathway [26].

However, there are conflicting results on the studies of calcium $[18,19]$. Additional clinical information is required to interpret these abnormalities, including fluid status, serum albumin, and ionized calcium concentrations. Therefore, we also evaluated the serum cCa levels in this study. In the present study, serum $\mathrm{Ca}$ levels of the patients who died were significantly lower than that of patients who survived. Low serum $\mathrm{Ca}$ levels in our study are probably related to the high prevalence of hypovitaminosis D in Turkey, and this may be a predisposing factor in our study population [27]. In the correlation analysis, there was a weak/moderate positive correlation between serum calcium level and lymphocyte, platelet and albumin; and there was a significant weak/moderate negative correlation between serum calcium level and CRP, LDH, creatinine, ferritin, PCT, and CURB-65 score. However, we could not find any significance in this regard with respect to cCa levels. Khamis et al. [28] found a relationship between low cCa level and high mortality in patients with COVID-19 who were hospitalized. A total of $38 \%$ of the hospitalized patients were admitted to the ICU. This difference may be due to the fact that there were no patients in our sample who were hospitalized in the ICU. On the other hand, in our study, a significant negative correlation was observed between serum cCa level and albumin level; and a weak/moderate positive correlation was found between serum cCa level and CRP, LDH, ferritin, PCT, troponin, CURB-65 score, and q-SOFA score. These results show that $\mathrm{cCa}$ levels are associated with certain prognostic factors.

In the present study, univariate logistic regression analysis revealed that age, respiratory rate, saturation, heart rate, lymphocyte, serum Ca, D-dimer, CURB-65 score, and q-SOFA score were independent predictors of high-risk group of mortality. These results demonstrate that there is a higher risk of hypocalcemia associated with COVID-19 disease. As in other studies, our study also showed that advanced age, respiratory rate, saturation, heart rate, lymphocyte, serum $\mathrm{Ca}$, Ddimer, CURB-65 score, and q-SOFA score were risk factors for mortality in patients with COVID-19 [4, 29-33]. In a retrospective cohort study, Zhou et al. [4] identified several risk factors of death in adults in Wuhan who were hospitalized with COVID-19. Similar to our results, in particular, advanced age, D-dimer levels $>1 \mu \mathrm{g} / \mathrm{mL}$, and higher SOFA score on admission were associated with higher odds of in-hospital mortality. Additionally, elevated levels of blood IL-6, high-sensitivity cardiac troponin I, LDH, and lymphopenia were more common in severe COVID-19 patients.

\section{CONCLUSION}

In conclusion, the results of this study reveal that serum Ca level in COVID-19 patients is a good prognostic parameter and an independent predictor for mortality, hypocalcemic patients have worse prognostic parameters, and there is a moderate/good correlation between serum $\mathrm{Ca}$ level and other parameters 
previously reported as prognostic factors for COVID19. Our results indicate that $\mathrm{Ca}$ and $\mathrm{cCa}$ assessment should be conducted upon patient initial presentation and disturbances in $\mathrm{Ca}$ and $\mathrm{cCa}$ levels should be monitored throughout the course of the disease in order to perform timely and appropriate corrective actions. Further research based on larger prospective cohort studies is necessary to confirm the findings presented in this study and to establish the clinical significance of our findings.

\section{Authors' Contribution}

Study Conception: İE, HÖ, MB, İKU, AÇ, RG; Study Design: İE, RG, AK, HU, ÖT; Supervision: AK, HU, ÖT; Funding: İE, MB, AÇ, RG; Materials: İE, $\mathrm{MB}, \mathrm{AÇ}, \mathrm{RG}$; Data Collection and/or Processing: İE, $\mathrm{MB}, \mathrm{AÇ}, \mathrm{RG}$; Statistical Analysis and/or Data Interpretation: İE, RG, AK, HU, ÖT; Literature Review: İE, HO, MB, İKU, AÇ, RG; Manuscript Preparation: İE, RG, AK, HU, ÖT and Critical Review: İE, AK, HU, ÖT.

\section{Conflict of interest}

The authors disclosed no conflict of interest during the preparation or publication of this manuscript.

\section{Financing}

The authors disclosed that they did not receive any grant during conduction or writing of this study.

\section{Acknowledgements}

The authors thank Enago - https://www.enago.com.tr/edit/ for their assistance in manuscript translation and editing.

\section{REFERENCES}

1. Huang C, Wang Y, Li X, Ren L, Zhao J, Hu Y, et al. Clinical features of patients infected with 2019 novel coronavirus in Wuhan, China. Lancet 2020;395:497-506.

2. Lu R, Zhao X, Li J, Niu P, Yang B, Wu H, et al. Genomic characterisation and epidemiology of 2019 novel coronavirus: implications for virus origins and receptor binding. Lancet 2020;395:565-74.

3. Aly MH, Rahman SS, Ahmed WA, Alghamedi MH, Al Shehri AA, Alkalkami AM, et al. Indicators of critical illness and predictors of mortality in COVID-19 patients. Infect Drug Resist 2020;13:1995-2000.

4. Zhou F, Yu T, Du R, Fan G, Liu Y, Liu Z, et al. Clinical course and risk factors for mortality of adult inpatients with COVID-19 in Wuhan, China: a retrospective cohort study. Lancet 2020;395:1054-62.

5. Petrilli CM, Jones SA, Yang J, Rajagopalan H, O'Donnell L, Chernyak Y, et al. Factors associated with hospital admission and critical illness among 5279 people with coronavirus disease 2019 in New York City: prospective cohort study. BMJ 2020;369:m1966.

6. Nasiri MJ, Haddadi S, Tahvildari A, Farsi Y, Arbabi M, Hasanzadeh S, et al. COVID-19 clinical characteristics, and sex-specific risk of mortality: systematic review and meta-analysis. Front Med (Lausanne) 2020;7:459.

7. Li X, Wang L, Yan S, Yang F, Xiang L, Zhu J, et al. Clinical characteristics of 25 death cases with COVID-19: a retrospective review of medical records in a single medical center, Wuhan, China. Int J Infect Dis 2020;94:128-32.

8. Guan WJ, Liang WH, Zhao Y, Liang HR, Chen ZS, Li YM, et al; China Medical Treatment Expert Group for COVID-19. Comorbidity and its impact on 1590 patients with COVID-19 in China: a nationwide analysis. Eur Respir J 2020;55:2000547.

9. Cao J, Tu WJ, Cheng W, Yu L, Liu YK, Hu X, et al. Clinical features and short-term outcomes of 102 patients with coronavirus disease 2019 in Wuhan, China. Clin Infect Dis 2020;71:748-55.

10. Xu Z, Shi L, Wang Y, Zhang J, Huang L, Zhang C, et al. Pathological findings of COVID-19 associated with acute respiratory distress syndrome. Lancet Respir Med 2020;8:420-2.

11. Mikami T, Miyashita H, Yamada T, Harrington M, Steinberg D, Dunn A, et al. Risk factors for mortality in patients with COVID-19 in New York City. J Gen Intern Med 2021;36:17-26. 12. Prasad N, Gopalakrishnan N, Sahay M, Gupta A, Agarwal SK; COVID-19 Working Group of Indian Society of Nephrology. Epidemiology, genomic structure, the molecular mechanism of injury, diagnosis and clinical manifestations of coronavirus infection: an overview. Indian J Nephrol 2020;30:143-54.

13. Zhou Y, Frey TK, Yang JJ. Viral calciomics: interplays between Ca2+ and virus. Cell Calcium 2009;46:1-17.

14. Olivier M. Modulation of host cell intracellular Ca2+. Parasitol Today 1996; 12:145-50.

15. Nieto-Torres JL, DeDiego ML, Verdiá-Báguena C, JimenezGuardeño JM, Regla-Nava JA, Fernandez-Delgado R, et al. Severe acute respiratory syndrome coronavirus envelope protein ion channel activity promotes virus fitness and pathogenesis. PLoS Pathog 2014;10:e1004077.

16. Nieto-Torres JL, Verdiá-Báguena C, Jimenez-Guardeño JM, Regla-Nava JA, Castaño-Rodriguez C, Fernandez-Delgado R, et al. Severe acute respiratory syndrome coronavirus $\mathrm{E}$ protein transports calcium ions and activates the NLRP3 inflammasome. Virology 2015;485:330-9.

17. Catalano A, Chilà D, Bellone F, Nicocia G, Martino G, Loddo I, et al. Incidence of hypocalcemia and hypercalcemia in hospitalized patients: is it changing? J Clin Transl Endocrinol 2018;13:9-13.

18. Cheungpasitporn W, Thongprayoon C, Mao MA, Kittanamongkolchai W, Sakhuja A, Erickson SB. Impact of admission serum calcium levels on mortality in hospitalized patients. Endocr Res 2018;43:116-23.

19. Akirov A, Gorshtein A, Shraga-Slutzky I, Shimon I. Calcium 
levels on admission and before discharge are associated with mortality risk in hospitalized patients. Endocrine 2017;57:34451.

20. WHO. Clinical management of severe acute respiratory infection when novel coronavirus (nCoV) infection is suspected: interim guidance, 25 January 2020 (2020). Available from: https://apps.who.int/iris/handle/10665/3308 [Accessed 30 March2020].

21. Sun JK, Zhang WH, Zou L, Liu Y, Li JJ, Kan XH, et al. Serum calcium as a biomarker of clinical severity and prognosis in patients with coronavirus disease 2019. Aging (Albany NY) 2020;12:11287-95.

22. Cappellini F, Brivio R, Casati M, Cavallero A, Contro E, Brambilla P. Low levels of total and ionized calcium in blood of COVID-19 patients. Clin Chem Lab Med 2020;58:e171-3.

23. Di Filippo L, Formenti AM, Rovere-Querini P, Carlucci M, Conte C, Ciceri F, et al. Hypocalcemia is highly prevalent and predicts hospitalization in patients with COVID-19. Endocrine 2020;68:475-8.

24. Bossoni S, Chiesa L, Giustina A. Severe hypocalcemia in a thyroidectomized woman with COVID-19 infection. Endocrine 2020;68:253-4.

25. Lippi G, South AM, Henry BM. Electrolyte imbalances in patients with severe coronavirus disease 2019 (COVID-19). Ann Clin Biochem 2020;57:262-5.

26. Cao M, Zhang D, Wang Y, Lu Y, Zhu X, Li Y, al. Clinical features of patients infected with the 2019 novel coronavirus (COVID-19) in Shanghai, China. medRxiv. 2020 Mar; 6. doi: https://doi.org/10.1101/2020.03.04.20030395.
27. Yesiltepe Mutlu G, Hatun S. Use of vitamin D in children and adults: frequently asked questions. J Clin Res Pediatr Endocrinol 2018;10:301-6.

28. Khamis F, Al-Zakwani I, Al Naamani H, Al Lawati S, Pandak $\mathrm{N}$, Omar MB, et al. Clinical characteristics and outcomes of the first 63 adult patients hospitalized with COVID-19: an experience from Oman. J Infect Public Health 2020;13:906-13.

29. Hoechter DJ, Becker-Pennrich A, Langrehr J, Bruegel M, Zwissler B, Schaefer S, et al. Higher procoagulatory potential but lower DIC score in COVID-19 ARDS patients compared to nonCOVID-19 ARDS patients. Thromb Res 2020;196:186-92.

30. Guan WJ, Ni ZY, Hu Y, Liang WH, Ou CQ, He JX, et al; China Medical Treatment Expert Group for COVID-19. Clinical characteristics of coronavirus disease 2019 in China. N Engl J Med 2020;382:1708-20.

31. Nguyen Y, Corre F, Honsel V, Curac S, Zarrouk V, Fantin B, et al. Applicability of the CURB-65 pneumonia severity score for outpatient treatment of COVID-19. J Infect 2020;81:e96-8.

32. Zhang L, Feng X, Zhang D, Jiang C, Mei H, Wang J, et al. Deep vein thrombosis in hospitalized patients with COVID-19 in Wuhan, China: prevalence, risk Factors, and outcome. Circulation 2020;142:114-28.

33. Rivera-Izquierdo M, Del Carmen Valero-Ubierna M, R-de1Amo JL, Fernández-García MÁ, Martínez-Diz S, Tahery-Mahmoud A, et al. Sociodemographic, clinical and laboratory factors on admission associated with COVID-19 mortality in hospitalized patients: a retrospective observational study. PLoS One 2020;15:e0235107. 